\title{
Role of culture in celebrity endorsement: Brand endorsement by celebrities in Indian context
}

\author{
Abhishek \\ Arvind Sahay
}

W.P. No. 2013-07-01

July 2013

The main objective of the working paper series of the IIMA is to help faculty members, research staff and doctoral students to speedily share their research findings with professional colleagues and test their research findings at the pre-publication stage. IIMA is committed to maintain academic freedom. The opinion(s), view(s) and conclusion(s) expressed in the working paper are those of the authors and not that of IIMA.

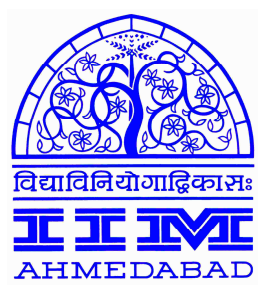

INDIAN INSTITUTE OF MANAGEMENT

AHMEDABAD-380 015

INDIA 


\title{
Role of culture in celebrity endorsement: Brand endorsement by celebrities in Indian context \\ A Review, Synthesis and Research Propositions
}

\author{
Abhishek \\ Assistant Professor, Marketing Area, Indian Institute of Management Ahmedabad \\ Email: abhishek@iimahd.ernet.in \\ Arvind Sahay \\ Professor, Marketing Area, Indian Institute of Management Ahmedabad \\ Email: asahay@iimahd.ernet.in
}

\begin{abstract}
Celebrity endorsement is a big market in India and continues to grow bigger. However, inspite of prevalent use of celebrities for endorsement, not all celebrity endorsements have been successful. The list of unsuccessful examples suggest that it will be wrong to consider celebrity endorsement as an effective response to media clutter in all situations inspite of the intensity of involvement people have with celebrities in India. In absence of existing celebrity endorsement theories to satisfactorily explain the phenomenon in India, this paper uses the lens of culture to develop propositions on how customer attitude towards celebrity endorsements is a function of cultural parameters in emerging countries like India. We build our argument by using culture to explain the congruence between celebrity and consumers for elaborating celebrity endorsement in Indian markets.
\end{abstract}

Key Words: celebrity endorsement, culture, congruence, emerging economy 


\section{Role of culture in celebrity endorsement: Brand endorsement by celebrities in Indian context A Review, Synthesis and Research Propositions}

\section{Introduction}

Though celebrity endorsements have been widely used by marketers in India and across the world, recent years saw burgeoning trend of celebrities being used by a number of brands in India. What started as a trickle in 1980s emerged as a phenomenon in 1990s with companies extensively using celebrities to communicate their brands to consumers. The rise in celebrity advertisement has been attributed to cluttering of media which has seen an increase in the number of brands advertised on TV from around 3,000 a decade ago to almost 11,500 (India Today - December 2004). It is said that for the same period, the number of commercials being aired is up by over 3,000 per cent (India Today - December 2004). Research conducted by leading Indian research agency IMRB indicated that $86 \%$ of the respondents say the most prominent advertisement that they remember has a celebrity in it (The Economic Times - 28 March, 2008). According to an estimate, the celebrity endorsement market is considered to be worth more than Rs. 10000 million (\$200 million) business (The Economic Times - 3 February, 2010).

With the onset of television as a powerful media for mass advertising in India in 1980s, a number of Indian brands like Vimal, Thums Up and Gwalior used star appeal during their early days of mass advertising. The role of celebrities in Indian context can be highlighted with the example of Coca Cola, who earlier never used celebrities internationally, but started using Indian celebrities for its advertisements in India in 1990s. Even a premium brand like Parker which commanded tremendous brand equity used leading Indian movie star Amitabh Bachchan to endorse the brand in India. The endorsement of Hyundai Santro car by leading 
actor Shah Rukh Khan has worked well for the brand as well as for the actor. Santro became the second largest selling car in India within four years of its launch and Shahrukh Khan, who was endorsing three brands, went on to endorse more than 30 brands in 2009 (The Hindustan Times - 17 September, 2012) .

However, inspite of prevalent use of celebrities for endorsement, not all celebrity endorsements have been successful even in India, as consumers were not able to identify with some celebrity advertisements. When Hindustan Unilever Limited (HUL) - Indian subsidiary of Unilever - tried to use Shahrukh Khan for endorsing Lux, by canvassing the image of a metro-sexual man, the promotion did not turn out to be very successful. Shahrukh Khan's association with Videocon, a leading white good manufacturer, had to be discontinued as the promotion did not give adequate results. Leading automobile company Maruti Suzuki was unable to exploit the 'Big B' status of Amitabh Bachchan for its Versa brand.

The list of unsuccessful examples suggest that it will be wrong to consider celebrity endorsement as an effective response to media clutter in all situations inspite of the intensity of involvement people have with celebrities in India. In order to enhance the effectiveness of celebrities, it has been suggested that marketers need to establish the link between the product and celebrity by considering the type of product. However, the utility of this theory - often explained as congruence between product and celebrity - in explaining the effectiveness of celebrity endorsement is limited as seen by the example of Shahrukh Khan endorsing Hyundai Santro and Amitabh Bachchan endorsing Versa. While both the brands belong to same product category and are endorsed by the leading Indian actors having pan-India appeal, the results have been quite different. 
In this paper, we review and synthesize the literature on celebrity endorsements and use the lens of culture to develop propositions on how customer attitudes towards celebrity endorsements is a function of cultural parameters. We build our argument by using culture to explain the congruence between celebrity and consumers for elaborating celebrity endorsement in Indian markets. The rest of the paper is organized as follows. First, we examine the literature on celebrity endorsements to understand the underlying theoretical underpinnings and identify the gaps and contradictions. Next, we summarize the dimensions of culture that are likely to influence the impact of celebrity endorsement on customer attitudes, with reference to the Indian context. Finally, we develop propositions that consider how different dimensions of culture influence the relationship between celebrity endorsements and customer attitude.

\section{Literature background}

\subsection{Celebrity endorsement process}

McCracken (1989) defined celebrity endorser as "any individual who enjoys public recognition and who uses this recognition on behalf of a consumer good by appearing with it in an advertisement" ( $\mathrm{p} 310$ ). Endorsement by celebrities is not a new phenomenon, however today celebrity endorsement has become one of the most popular forms of advertising (Choi \& Rifon, 2007) including in the non-profit sector (de los Salmones, Dominguez, \& Herrero, 2013). The current popularity of celebrity endorsements can be attributed to the numerous benefits companies have seen by utilizing this form of advertisement. In today's media cluttered environment where it is difficult to grab consumer's attention, marketing managers are looking for celebrities to gather attention and mileage, giving companies a better chance of communicating their message to consumers (Erdogan, Baker, \& Tagg, 2001; Kamins, 
Brand, Hoeke, \& Moe, 1989). In addition to getting consumers to listen to the advertisement, the use of celebrities is also believed to help consumers remember the message of the advertisement and the brand name the celebrity is endorsing (Agrawal \& Kamakura, 1995; Erdogan, 1999; Freidman \& Friedman, 1979; Misra \& Beatty, 1990). Also, in another major advantage in employing celebrity endorsement, celebrities bring their own distinctive images to the advertisement and its associated brand and can create, enhance and change brand image (Erdogan, 1999). According to Agrawal and Kamakura (1995), when a celebrity is paired with a brand, her image helps shape the image of that brand in minds of the consumer.

Although research findings are equivocal about the ability of celebrities to generate actual purchase behavior, positive impact on economic returns of sponsoring companies is well documented (Agarwal \& Kamakura, 1995; Chung, Derdenger, \& Srinivasan, 2013; Elberse \& Verleun, 2012; Mathur, Mathur, \& Rangan, 1997). Also, despite the debate on effectiveness on use of celebrity endorsers, it is widely accepted that celebrity endorsers are more effective than non-celebrity endorsers in generating all desirable outcomes (attitudes towards advertising and endorsed brand, intentions to purchase, and actual sales) when companies utilize celebrities whose public persona match with the products and target audiences (Erdogan, 1999).

Research in area of celebrity endorsement has focused on understanding the process by which the celebrities add value to company, brand or product. Many scholars have attempted to construct models to explain the celebrity endorsement process. These include the Source Credibility Model, the Source Attractiveness Model, the Product Match-up Hypothesis, and the Meanings Transfer Model. 
The Source Credibility Model and the Source Attractiveness Model are categorized under the generic name of Source Models since these two models basically inform and reflect research of Social Influence Theory / Source Effect theory which argues that various characteristics of a perceived communication source may have a beneficial effect on message receptivity (Erdogan, 1999). The Source Credibility Model proposes that the effectiveness of a message depends on perceived level of expertise and trustworthiness in an endorser (Ohanian, 1991). On the other hand, in the Source Attractiveness Model, it is contended that the effectiveness of a message depends on similarity, familiarity and liking for an endorser (McGuire, 1985). However the Source Models alone cannot explain the effects of celebrity endorsers (McCracken, 1989).

The Product Match-Up Hypothesis maintains that messages conveyed by celebrity image and the product message should be congruent for effective advertising (Kamins \& Gupta, 1994). The determinant of the match between celebrity and brand depends upon the degree of perceived fit between brand and celebrity image. Advertising a product via celebrity who has a relatively high product congruent image leads to greater advertiser and celebrity believability relative to an advertisement with a less congruent product/spokesperson image. DeSarbo and Harshman (1985) argued that neither the Source Models (Credibility and Attractiveness) nor the Product Match-Up Hypothesis is adequate in providing a heuristic for appropriate celebrity endorser selection. They stated a number of problems with these models namely these model do not provide measures to cope with multidimensionality of source effects, these approaches ignore overtone-meaning-interactions between a celebrity and the product endorsed, and there is a lack of qualified empirical basis for purposed dimensions. 
Inspite of the criticisms against the product match-up hypothesis, it has emerged as the dominant paradigm in celebrity endorsement literature with recent research (Carrillat, d'Astous, \& Lazure, 2013; Fleck, Korchia, \& Le Roy, 2012; Gurel-Atay \& Kahle, 2010; Lee \& Thorson, 2008) highlighting the role of congruence between product/brand and celebrity as an important factor for successful celebrity endorsement.

Belk (1988) pointed out that consumer view the products they purchase as much more than just "bundles of utility" as economists proclaim, but also as "bundles of meaning" or attributes like sophistication, courageousness, frugality, and honesty, with which to fashion their self-identity. Companies attempt to label their products with different meanings by linking their products with celebrities who carry the meanings they desire. During celebrity endorsement, consumers have a perceived image about any celebrity endorser, and this image affect is transferred to the endorsed brand (Atkin and Block, 1983).

Explaining this transference of image, the Meanings Transfer Model (McCracken, 1989) stated that celebrities develop a persona through the type of roles they play in society as well as how they are portrayed in the media. Collectively, the culturally constituted society then assigns meanings to the celebrities. When celebrities endorse a product, the meaning developed around a particular celebrity will transfer to a company, brand, or product. When a consumer identifies with a celebrity, he/she purchases the product in hope of claiming some of these transferred meanings for their own lives. The effectiveness of a celebrity endorser compared with an anonymous endorser lies in bringing a distinguishing feature in terms of personality and lifestyle meanings to an endorsement process (McCracken, 1989). 
However, we contend that transference of these meanings will be affected by the cultural moorings of the consumers and they are likely to influence the impact that a celebrity endorsement will have upon company, brand or product; that, in fact, the congruence between the celebrity and the consumer matters in addition to congruence between celebrity and product. Markus and Kitayama (1991) have argued that culture has a profound impact on the dominant self conceptions that exist within a given culture. Although theorists may well differ in the emphasis that they give to the different dimensions of culture, there is increasingly the recognition that national cultural values affect the cognitive, the emotional and the motivational patterns dominant of customers in a given culture (Markus \& Kitayama, 1991).

Research in recent years have shown that universal applicability of many marketing models may not be true (de Mooij \& Hofstede, 2010). Previous research in marketing and consumer behavior has found culture to be an important determinant of consumer behavior (Aaker \& Lee, 2001; Farley \& Lehman, 1994). Hofstede's (1980, 2001) work sensitized marketing scholars to the role of culture in marketing models. Researchers who previously had not questioned whether theories of human behavior were applicable to all people were provided with a systematic framework of cultural dimensions suggesting that not only behavior but also the processes and mechanisms governing behavior could be captured along different cultural dimensions.

Since these dimensions of culture proposed by Hofstede (1980) were published, researchers have confirmed them in various cultures around the world and have used them to analyze 
many marketing issues, such as variations in symbolic consumption behavior, consumer responses to advertising, and marketing management practices in various cultural settings. In this paper, we use dimensions of culture to explain the congruence between the celebrity and the consumers in celebrity endorsement. The congruence between celebrity and consumer for explaining the effect of celebrity endorsement is a relatively unexplored area (Choi \& Rifin, 2012). Till now all the research related to congruence in celebrity endorsement has focused on match between the product and endorser. In this paper, we contend that congruence between celebrity and consumer in celebrity endorsement can be explained by dimensions of culture; that this congruence explains some of the phenomenon related with celebrity endorsement in Indian context.

\subsection{Dimensions of culture}

Culture has long been believed to be the force that influences people in a society to follow the norms of their collective identity. Kroebar and Parsons (1958) defined culture as "transmitted and created content and pattern of values, ideas, and other symbolic-meaningful systems as factors in shaping of human behavior and the artifacts produced through behavior". A similar definition was given by Taylor (1964) in which culture is defined as that complex whole which includes knowledge, belief, art, morals, law, custom and any other capabilities and habits acquired by man as member of society. In his seminal study on culture, Hofstede (1980) treated culture as the collective programming of the mind that distinguishes the members of one group or category of people from another. He defined culture as the interactive aggregate of common characteristics that influence a human group's response to its environment. Sojka and Tansuhaj (1995) conducted a review of twenty years of crosscultural research and provided their definition of culture as a dynamic set of socially acquired 
behavior patterns and meanings common to members of a particular society or human group, including the key elements of language, artifacts, beliefs and values.

The above-mentioned definitions imply that culture presupposes a collectivity and the word can be applied to any human collectivity or category. Culture has to do with shared ideas, the way a group of people conceptualize and represent the world and life to themselves, thus differentiating people of one society from another. The word culture is usually reserved for societies and it has been operationalized as nations or as ethnic or regional groups within or across nations (Hofstede, 2001). Schwartz (1999) stated that national boundaries do not necessarily correspond to the boundaries of organically developed, relatively homogeneous societies with a shared culture but there are strong forces towards integration that can produce substantial sharing of culture in nations that have existed for some time. A country's culture has long been identified as a key environmental characteristic underlying systematic differences in consumer behavior; cultural norms and beliefs are powerful forces shaping people's perceptions, dispositions, and behaviors (Markus \& Kitayama, 1991).

While culture can never be treated as a single independent variable, for it is a loaded and complex variable, overarching many areas in life (Christie, Kwon, Syoeberl, \& Baumhart, 2003) and culture includes an extensive number of dimensions and values, much of the research on culture is concerned about understanding cultural values i.e. shared beliefs about how people should behave. There have been a number of studies to identify core values across societies, and those values that differ between societies and are a result of local cultural differences (Burton, 2009). 
One of the earliest attempts toward proposing cultural categories for analyzing culture came from Kluckhohn and Strodtbeck (1961). They proposed six cultural dimensions namely the nature of people, the person's relationship to nature, the person's relationship to others, the modality of human activity, temporal focus of human activity, and conception of space. Hofstede (1980) presented one of the first empirically validated typology of culture across different nations. He identified four dimensions of culture on which a country's culture could be placed. He named them as power distance, uncertainty avoidance, individualismcollectivism, and masculinity-femininity. Later, based on the work done by Michael Bond (1988), Hofstede added a new dimension of long-term versus short-term orientation to extend the number of dimensions to five.

Trompenaars (1993), based on Parson's (1951) sociological study about relational orientations, offered five cultural dimensions which he named as universalism versus particularism, individualism versus collectivism, neutral versus emotional, specific versus diffuse, and achievement versus anticipation. He later added two more dimension namely attitude toward time and environment and used these dimensions for practical issues which concern businesspeople (Beamer \& Valentine, 2000).

Schwartz (1994) critiqued the current theories of cultural values for addressing limited aspects of culture and developed a theory of type of values on which culture can be compared. He validated his theory with data from 49 countries around the world which represented all important regions of the world, thus addressing one critical limitation of Hofstede's study which did not include data from former Eastern bloc countries. The empirical analysis validated seven values which were structured along three polar 
dimensions: conservatism versus intellectual and affective autonomy; hierarchy versus egalitarianism; and mastery versus harmony.

The three frameworks proposed by Hofstede, Trompenaars, and Schwartz shared the similar conceptual view of culture in that they consider each culture, i.e. country to have a shared set of core values and norms guiding their member's behavior. However, among the numerous studies, Hofstede work to identify value systems across different cultures has been most well accepted and most widely cited (Bond, 2002). The typology of cultural dimensions proposed by Hofstede is used for this study since it has been extensively used in marketing and advertising literature to study cross-national differences (e.g., Singh, 2004; Petersen, Kushwaha, \& Kumar, 2013). Moreover, it has been repeatedly validated over time in a number of countries for research related to advertising (e.g., Biswas, Hussain, \& O'Donnell, 2009; Choi \& Rifon, 2007; Money, Shimp, \& Sakano, 2006).

Choi, Lee and Kim (2005) maintained that despite the importance of celebrity in marketing promotional strategies, there have been few studies of the different incidences of celebrity endorsement across the countries and they tend to be limited to assessing the frequency of appearance. This is an important omission since the percentage of advertisements worldwide that feature a celebrity has doubled in a little over a decade (Money et al, 2006). Choi et al. (2005) stated that differences in consumer dispositions towards celebrity endorsements are likely to lead to observed cross-cultural differences in the use of this technique. This brings to fore the importance of analyzing the celebrity endorsement process across different cultures. 
As most of the models of celebrity endorsement process have been developed in the context of United States, it was decided to use India and United States as these societies differ considerably on many dimensions of culture. In addition, one exemplifies an advanced developed economy, the other is representative of an emerging economy. We expect that the differences in dimensions of culture between India and United States would account for the peculiarities of celebrity endorsement process in India. Hofstede found that two countries can be closely similar in a particular cultural dimension and highly dissimilar in various other dimensions. For example, India and the United States are greatly similar in the uncertainty avoidance index, but exceedingly dissimilar in the individualism index. Hofstede reported differences between the Indian and American cultures on three of these dimensions: power distance, individualism-collectivism, and long-term versus short-term orientation. We briefly discuss the cultural differences on these three dimensions.

\subsubsection{Power distance}

The term power distance is borrowed from the social psychologist Mulder, who in 1960s conducted experiments to investigate interpersonal power dynamics. Different societies and countries put different weights on status consistency in areas such as social status and prestige, physical and mental characteristics, wealth, and power (Hofstede, 2001). Power distance explains the way a society handles inequality among its members. Hofstede defined power distance as "the extent to which the less powerful members of institutions and organizations within a country expect and accept that power is distributed unequally".

The countries covered by Hofstede were given a score on power distance based on Power Distance Index. A high power distance ranking indicated inequalities of power and wealth 
while a low power distance ranking indicated that society de-emphasizes the differences between citizen power and wealth. In former case, country people believe in authoritarian values and a centralized system but in latter case, equality and opportunity for everyone is stressed. India has a score of 77 on Power Distance Index against the United States score of 40. India's score indicates a high level of inequality of power within the society whereas US score is indicative of greater social equality.

\subsubsection{Individualism-collectivism}

Individualism and collectivism describe the relationship between the individual and the collectivity that prevails in a given society. Individualism pertains to societies in which the ties between individuals are loose: everyone is expected to look after himself or herself and his or her immediate family (Hofstede, 2001). On the other hand, collectivism pertain to societies in which the ties between individuals are close: it pertains to societies in which people from birth onwards are integrated into strong, cohesive in-groups, which throughout people's lifetime continue to protect them in exchange for unquestionable loyalty (Hofstede, 1991). In these societies, culture reinforces extended families and collectives where everyone takes responsibility for fellow members of their group.

The dimensions of individualism and collectivism are measured by Individualism Index. A high score on Individualism Index indicates that individuality and individual rights are emphasized within the community. Alternatively, a low score on Individualism Index signifies a nation of collectivist nature with close ties between individuals and close family members. The United States has score of 91 on Individualism Index, which incidentally is also the highest score on Individualism Index, suggesting a society with high individualistic 
attitudes. India's score on Individualism Index is 48 , which is slightly below the world average of 50, indicating a society with high collective orientation.

\subsubsection{Long versus short term orientation}

Long-term orientation characterizes cultures which place more importance on values associated with future orientation while short-term orientation cultures place more importance on values associated with past and present orientations. Hofstede (2001) defined long-term orientation as standing for the fostering of virtues oriented towards future rewards, in particular perseverance and thrift. Its opposite short term orientation was defined as standing for fostering of values related to the past and present, in particular respect for tradition, preservation of 'face' and fulfilling social obligations.

This dimension is measured by Long-Term Orientation Index in which a high score indicates long term orientation. India's score on Long-Term Orientation Index is 61 in comparison to world's average of 48, indicating a culture with long term orientation. On the other hand, United States score is 29 reflecting a culture with short term perspective. Since the cultural context of Indians evaluating celebrities is markedly different from that of an American, our premise, therefore, is that there should be differences relating to the impact of celebrity advertisement

Having examined the literature for celebrity endorsement advertising and dimensions of culture, in the next section, we develop the propositions to explain the celebrity endorsement process in the context of an emerging economy like India. The difference in cultural dimensions between United States and India has been employed for developing the propositions. The explanations have been structured on the lines of India's position in the 
different dimensions and can be extended for countries having similar scores as India in Hofstede's dimensions of culture. While developing the propositions using dimensions of culture, we have considered that congruence between the celebrity and the consumer will lead to better effectiveness of celebrity. Almost sixty year ago, Osgood and Tannenbaum (1955) proposed the principle of congruity for attitude change in which authors noted that "changes in evaluation are always in the direction of increased congruity with the existing frame of reference" ( $p$ 43). This was based on the theories of cognitive psychology concerning the structure of knowledge in which a congruent combination was easier to understand and memorize in comparison to incongruent combination (Fleck, \& Maille, 2010). Additionally, the congruence conviction was also supported by balance theory (Heider, 1958) which pointed out that an individual prefers information which does not trouble her internal equilibrium. Over the years, many streams of research in marketing like brand extension, cobranding, and advertising have shown that congruence is a positive factor and it is preferable over incongruence (Fleck \& Quester, 2007). While explaining the role of culture in celebrity endorsement, we use the same logic of congruence to state the propositions in the following sections.

\section{Propositions - Celebrity endorsement process in India}

\subsection{Popularity of celebrities}

While the use of celebrities in advertisement in global phenomenon, its high incidence in India can have explanations emanating from power distance dimension of culture. As per Hofstede (2001) study, the power distance index score for India is 77 which will be considered significantly higher than United States score of 40 , and thus pointing towards a culture of high power distance. A culture of high power distance signifies inequality in the 
society. The existence of class and caste manifests the inequalities in this dimension. Hofstede (2001) pointed that these inequalities can occur in area like prestige, wealth, and power and generally values about inequality are coupled with values about the exercise of power.

French and Raven (1959) provided five bases of social power namely reward power, coercive power, legitimate power, referent power, and expert power. In countries of high power distance, Hofstede (2001) surmised that more referent power which is based on personal charisma of the powerful and identification with him or her by the less powerful, will prevail. In India, which is a stratified society, persons belonging to lower classes have deference towards the members of higher ranks. The mental programming for their hierarchical roles gets affected and strengthened by their exposure to societal norms like those involving relationship between parents and child and of teacher and pupil. This also gets reflected in case of successful artists and athletes who enjoy status due to their unique physical and/or mental characteristics. People take successful artists and athletes as having referent power and identify themselves with them in various ways like idolizing them, revering them, and imitating them and their life-styles. This is less likely to happen in a society that is low on power distance where idolization, revering and identification will be less effective. The popularity of different artists and athletes through celebrity advertisements can be considered one of the manifestations of this referent power. Consumers see the endorsement by celebrities in congruence with this manifestation of referent power. Thus, we propose

P1: Attitude towards a celebrity will be more positive in a society having higher power distance in comparison to society having lower power distance. Thus, the greater the power distance in a society, the greater the likelihood of "congruence" between the celebrity and the consumer. 
When we look at the celebrity endorsements for different brands across product and service categories in Indian market, we find that the rise in celebrity endorsements has been phenomenal in decade to 2010. In 2001, $25 \%$ of all TV advertisements carried a known face. By 2008, this had grown to $60 \%$ and continues to grow (The Economic Times, 3 February, 2010). In 2007, only 88 brands used celebrities, while 98 brands used celebrities to push their products in 2008 (The Economic Times, 25 March, 2009). The last few years have seen companies like Hero Honda, Airtel, Pepsi, and Sahara Homes employing multiple celebrities to endorse their product. The surge in celebrity advertisements is in contrast to the advertising scene in United States where inspite of increase in incidence of celebrity advertising, only about $25 \%$ of advertisements feature celebrities (Money et al., 2006). Practitioner's persistent use of celebrity endorsers in emerging markets like India suggests that celebrity endorsement is likely to prove an effective advertising strategy in these markets (Amos, Holmes, \& Strutton, 2008).

\subsection{Multiple endorsements by celebrities}

Generally, multiple endorsements by celebrities are known to make celebrity likeability less favourable (Rice, Kelting, \& Lutz, 2012; Tripp, Jensen, \& Carlson, 1994). When we look at world of celebrity endorsement in India, we see that a number of celebrities are engaged in multiple endorsements. In a high power distance country like India, generally the celebrities in India have high reverence factor and there prevails a larger than life status for the celebrities leading to celebrities having greater referent and legitimate power. Often this larger than life status leads the celebrities to hold command over not only their area of expertise but over a range of other areas as well. As a result, the celebrity is not seen as expert in one area only but one can associate these celebrities with multiple domains. While consistent with the meaning transference thesis of McCracken (1989), the meaning 
transference takes place on a different basis - that of individual's identification with the celebrity's persona rather than acceptance of the celebrity's meaning and congruence in relation to the brand. Accordingly, if the celebrities endorse products for which the congruency between product and celebrity may not be present, it does not diminish the effectiveness of celebrity because the congruence is established between consumer and celebrity's persona. Thus one can expect that celebrities in high PDI countries like India will endorse more number of brands in comparison to celebrities in low PDI countries like United States. Therefore, we propose

P2: In case of a celebrity endorsing multiple brands, the consumer attitude towards celebrity will be more positive in a society having higher power distance in comparison to society having lower power distance.

In India, while most brands will proclaim that they will only make endorsements deals that fit well with endorser's image, in reality, each endorser's portfolio consists of diverse brands. At one point of time, Amitabh Bachchan was endorsing more than 50 brands across disparate product categories. Currently Shahrukh Khan and Mahindra Singh Dhoni (captain of Indian cricket team) are leading endorsers with each endorsing close to 20 brands. As per estimates by AdEx, Shahrukh Khan endorsed 17 brands in 2009 while Dhoni led the year with 19 endorsements. The leading Bollywood ladies like Katrina Kaif and Priyanka Chopra endorsed 12 and 10 brands respectively (The Economic Times - 3 February, 2010). The power distance dimension of culture provides an explanation for the same in emerging countries like India whose score on PDI is different from United States. 


\subsection{Impact of regional celebrities}

A large country like India has seen emergence of regional celebrities who are used for endorsing a brand in a particular geographical area. The explanation for strong acceptance of celebrities in the areas from where they hail can be attributed to the individualism/collectivism dimension of the culture. India having a score of 48 on individualism index signifies a nation of collectivist nature. In case of collectivist culture, there is emotional dependence on groups, organizations, or other collectivities. Children are taught to think in terms of "we" and consequently, the emphasis is on belonging and one builds ties with members of in-groups (wherein people share as much as possible the same background). Often friendships are determined by social network. The in-group is the major source of one's identity and therefore one owns loyalty to one's in-group (Hofstede, 2001). When a celebrity endorses a brand, other members who are from same social network or consider themselves to be from same in-group, consider it as their obligation to support the celebrity. This is, often, based on their socialization wherein they believe it as a way of creating ties with celebrities and to socially integrate into celebrity's in-group. The fact that self-concept in collectivist societies is expressed in groups (Hofstede, 2001) further adds to the effect. Consumers see the celebrity endorsement as an extension of the congruence between consumer and celebrity. Therefore for celebrity endorsement, where a strong regional identification is associated with the celebrity, the consumers in that particular region show solidarity with the celebrity. As a result, a brand endorsed by a celebrity often finds strong support in the area from where the celebrities hail. This is summarized in following proposition. 
P3: In case of endorsement by local celebrity, the attitude towards celebrity will be more positive in a society having higher collectivism in comparison to society having higher individualism.

When we look at Indian celebrity endorsement scene, we see that when Mahendra Singh Dhoni became the number one batsman and captain of Indian cricket team, it led to spurt in sales of products endorsed by him in Ranchi - capital of his home state Jharkhand. Dhoni struck an emotional chord with the people of his state and this impacted the sale of his endorsed products - from motorcycles to fans. According to some reports, the sale of TVS Star City motorbike shot up by $80 \%$. Similarly, although Katrina Kaif was the most searched celebrity on internet across the country, Aishwarya Rai topped the search charts in Konkan region states like Goa and Karnataka (The Economic Times - 26 July, 2009) from where she hailed. In early 1980s, when leading actor Dharmendra endorsed Rajdoot motorcycle, its sale increased significantly in state of Punjab, from where Dharmendra hailed. The trend has been realized by corporates in India who have used regional stars for promoting their products in particular states while continuing with national level stars for national campaigns. Such examples include Dabur using Ravi Kishan in northern state of Uttar Pradesh, Pepsi using Simran for Kurkure in South India, and Emami using Surya for Fair and Handsome in state of Andhra Pradesh.

\subsection{Celebrity endorsement in crisis management}

There are many examples where companies in India have used celebrities to overcome the crisis related with their brands. The long-term orientation dimension of culture where India has a score of 61 on Long-Term Orientation Index provides some indication for explaining the use of celebrity endorsement in turning around the crisis involving brand. In case of long 
term orientation country like India where relationships ordered by status prevails and this order is observed (Hofstede, 2001), the celebrity endorsers capitalize on these relationships built over the years and are able to reduce the negative feelings towards the brands. When celebrities endorse a brand in crisis, they are able to transfer the meanings associated with themselves to reverse the negative news about brand in crisis because of the existing congruence between the celebrity and the consumer. The explanation for the same can be based on McCracken's work (1989) who theorized that celebrities bring their own culturally constituted meanings to the endorsement process. Alternatively, it has been proposed by some scholars that associative learning theory can explain the process in which celebrity's unique attributes are transferred to the brand (Till, 1998; Till and Shimp, 1998). According to associative learning theory, memory can be considered to be a network of various nodes which are connected by associative links (Anderson, 1976). The pairing of two stimuli (celebrity and brand) builds a link between the nodes wherein the feeling and meanings towards a celebrity will transfer to the endorsed brand. Thus, the congruence between the celebrity and consumer is able to overcome the negativities associated with brand. This is also aided by the fact that in long term orientation culture, people do not have probabilistic thinking (Hofstede, 2001) and in case they believe the celebrity endorser, they have full confidence in the celebrity as well as brand. Accordingly companies in India employ celebrity endorsers for countering the negative news about brands and it turns out to be effective. Thus, we propose

P4: When a celebrity endorses a brand which is facing negative news, the attitude toward a brand will turn more positive in a society having long term orientation in comparison to society having short term orientation. 
When a neutral research group (Center for Science and Environment, an independent public interest group) in India alleged that soft drinks manufactured by Coca Cola contained harmful pesticide residue, the company responded by bringing in celebrity endorsement. Aamir Khan, a leading actor - who enjoys a tremendous fan-base in India, appeared in a television commercial defending Coke and gulping a bottle of the beverage while endorsing Coke's security standards. Earlier, Cadbury faced a major embarrassment in 2004 when worms were found in some of its packages in India. Cadbury tried to overcome the worm infestation controversy by vouching for its quality and safety standards. However as the public was not convinced by company's assurances, Cadbury turned to Amitabh Bachchan to bail it out. Amitabh Bachchan, with assuring personality and a pan-India appeal, salvaged Cadbury's reputation by reinforcing the point that Cadbury had made substantial changes in packaging and was paying attention towards its storage conditions in retail outlets.

\subsection{Negative information about celebrity}

Amos, Holmes, and Strutton (2008), though a meta-analysis, found that negative information about the celebrity exercised largest impact on celebrity endorsement effectiveness. However, in India, it has been seen that even when celebrity endorsers go through a bad patch which may lead to a drop in their star power, companies continue with them. In such cases, the explanation for the phenomenon can be, once again, provided by power distance as well as individualism/collectivism dimension of culture.

As mentioned earlier, generally the celebrities in India have high reverence factor and there prevails a larger than life status for the celebrities. Also, in a collectivist society like India self-image is based on interconnectedness of people, fitting in, and interdependence with 
others. Celebrities who are high on status and are able to build franchises with their fans and are often able to sustain it because for individuals with a long term orientation in a country like India, relationships ordered by status prevails and this order is observed (Hofstede, 2001). Thus even in case of negative information about the celebrities, if the celebrity is on a high pedestal, it will not result into significant degradation of his/her power base. The congruence between the celebrity and consumer, built over the years, sustains due to longterm orientation of culture. Ultimately in such cases, negative impact on brand endorsement by celebrities will be lesser in countries like India. Moreover, even in case of negative impact, the process would be much slower, due to high power distance in the society, thereby reducing the impact. Thus, we propose

P5: In case of negative news about a celebrity, its impact on attitude towards celebrity will be less negative in a society having higher power distance and long term orientation in comparison to a society having lower power distance and short term orientation.

We see that though some of the celebrity endorsers like cricket players Mohammed Azharuddin and Ajay Jadeja were dropped by their respective brands after being dragged into the betting controversy, most of the times in India, the celebrity endorsers continue to enjoy the confidence of brands even in case of negative publicity. There are examples like Salman Khan who inspite of involved in cases like shooting down the endangered black buck or allegedly mowing down people who were sleeping on a Mumbai pavement, has appeared for brands like Perfetti's Chlormint, HUL's Wheel, and Sangini jewellery. When Saurabh Ganguly, the then Indian cricket captain was dropped from the team and has been struggling to make a comeback, Pepsi decided not to drop him from the advertisements. Thus one can surmise that even when celebrity endorsers go through a bad patch which may lead to a drop in their star power, companies continue their association. 


\section{The way forward}

The purpose of this paper was to review and synthesize the literature on celebrity endorsements in the light of widely differing practices in nature and quantity of use of the phenomena between developed and emerging markets and to develop a set of propositions that explain the difference using the lens of culture. The propositions explained in earlier section need to be empirically verified before they can be generalized. The empirical verification will require careful consideration of a number of issues. First is the issue of sampling. Hofstede's cultural study was based on narrow and specific sample of their countries' population. This sample belonged to the middle class of their society rather than to the mix of upper, middle, working, and peasant class (Hofstede, 1983). Similarly, study by Schwartz (1999) collected data from teachers and students, a context different from business environment which was the basis for Hofstede's data collection exercise. When we talk about a country like India which is made up of several sub-cultures, it is imperative to have generalizations based on broad sample strategy - which is representative of entire population.

While we apply the various dimensions proposed by Hofstede for explaining the difference in celebrity advertising process between United States and India, we also need to be cognizant of the time relevancy of the findings. Dependence on Hofstede means that marketers often build their models and taxonomic assumptions about cultural aspects of markets which originate from data on work values which was obtained 40 years ago (Holden, 2004). Substantial modernization has taken place in most of the surveyed countries including India. Hofstede (1980) saw different dimensions as indicators embedded in a dynamic process of cultural development which were shifting as social, structural, and historical changes were occurring. Thus, Hofstede warned that his own results were not stable but rather shaped by 
the economic and historical circumstances of the period, when he collected his data. He was able to demonstrate this flux by comparing responses collected a few years apart in his first and second data sets (Oyserman, Coon, \& Kemmelmeier, 2002). Empirical validation will need to incorporate the knowledge that environmental factors such as political, legal, and economic systems affect the value systems of population and will have to be considered when values are considered (Hofstede, 1980).

Also, with respect to individualism and collectivism dimension, Triandis (2004) stated that a number of topics have been found to be relevant to individualism and collectivism which underscores its importance of this dimension. However, he also added that most of the research has been done in East Asia and North America, and we are not yet sure that the findings will also apply to other collectivist and individualistic cultures. Moreover, It has been pointed out that there are some similarities and some differences among aspects of collectivism (Fiske, 2002), and different forms of culture probably vary along different facets of collectivism. For example, within India we expect to find variation in distribution of collectivism-individualism dimension as urban samples tend to be relatively more individualistic and traditional rural samples tend more toward collectivism. We can learn more about these facets of dimensions of collectivism if we study collectivism not just across nations but across differing religions, social classes, and regions of countries (Cohen, 2009). Data collection in order to validate the explanations will have to look at all these aspects. Nevertheless, within the above constraints, our paper contributes to the literature by (a) bring in the notion of congruence between the celebrity and the consumer as a driver of effectiveness of celebrity endorsements and (b) by offering propositions using the dimensions of culture (like individualism-collectivism, power distance and long term orientation) to suggest ways in which this congruence manifests itself. 


\section{References}

Aaker, J. \& Lee, A. (2001) "I" seek pleasures and "We" avoid pains: The role of selfregulatory goals in information processing and persuasion. Journal of Consumer Research, 28(1), 33-49.

Agrawal, J., \& Kamakura, W. (1995) The economic worth of celebrity endorsers: An event study analysis. Journal of Marketing, 59(3), 56-62.

Anderson, J. R. (1976) Language, memory, and thought. Hillsdale, NJ: Lawrence Erlbaum Associates.

Atkin, C. \& Block, M. (1983) Effectiveness of celebrity endorsers. Journal of Advertising Research, 23(1), 57-61.

Bansal, Neelima Mahajan, "Does celeb ad blitz really push up sales?" The Economic Times, March 28, 2008.

Beamer, L. \& Valentine, D. (2000) Finding a way to teach cultural dimensions. Business Communication Quarterly, 63(3), 111-118.

Belk, R. W. (1988) Possessions and the extended self, Journal of Consumer Research. 15(2), 139-168.

Biswas, S., Hussain, M., \& O'Donnell, K. (2009). Celebrity endorsements in advertisements and consumer perceptions: A cross-cultural study. Journal Of Global Marketing, 22(2), 121-137.

Bond, M. (1988) Finding universal dimensions of individual variation in multicultural studies of values: The Rokeach and Chinese value surveys. Journal of Personality and Social Psychology, 55(6), 1009-1015.

Bond, M. (2002). Reclaiming the individual from Hofstede's ecological analysis - a 20 year odyssey: Comment on Oyserman et al. (2002). Psychological Bulletin, 128(1), 73-77

Burton, D. (2009) Cross-cultural marketing. New York: Routledge.

Carrillat, F. A., d'Astous, A., \& Lazure, J. (2013). For better, for worse?: What to do when celebrity endorsements go bad. Journal Of Advertising Research, 53(1), 15-30.

Choi, S., Lee, W. \& Kim, H. (2005) Lessons from the rich and famous. Journal of Advertising, 34(2), 85-98.

Choi, S. \& Rifon, N. (2007) Who is the celebrity in advertising? Understanding dimensions of celebrity images. Journal of Popular Culture, 40(2), 304-324. 
Choi, S., \& Rifon, N. J. (2012). It is a match: The impact of congruence between celebrity image and consumer ideal self on endorsement effectiveness. Psychology \& Marketing, 29(9), 639-650.

Christie, P., Kwon, I., Stoeberl, P. \& Baumhart, R. (2003) A cross-cultural comparison of ethical attitudes of business managers: India, Korea and the United States. Journal of Business Ethics, 46(3), 263-287.

Chung, K. C., Derdenger, T. P., \& Srinivasan, K. (2013). Economic value of celebrity endorsements: Tiger Woods' impact on sales of Nike golf balls. Marketing Science, $32(2), 271-293$.

Cohen, A. (2009) Many forms of culture. American Psychologist, 64(3), 194-204.

de los Salmones, M., Dominguez, R., \& Herrero, A. (2013). Communication using celebrities in the non-profit sector: Determinants of its effectiveness. International Journal of Advertising, 32(1), 101-119.

de Mooij, M., \& Hofstede, G. (2010). The Hofstede model. International Journal of Advertising, 29(1), 85-110.

DeSarbo, W. \& Harshman, R. (1985) Celebrity-brand congruence analysis. Current Issues \& Research in Advertising, 8(2), 17-52.

Erdogan, B. (1999) Celebrity endorsement: A literature review. Journal of Marketing Management, 15(4), 291-314.

Erdogan, B., Baker, M. \& Tagg, S. (2001) Selecting celebrity endorsers: The practitioner's perspective. Journal of Advertising Research, 41(3), 39-48.

Elberse, A., \& Verleun, J. (2012). The economic value of celebrity endorsements. Journal Of Advertising Research, 52(2), 149-165.

Farley, J. U. \& Lehman, D. R. (1994) Cross-national 'laws' and differences in market response. Management Science, 40(1), 111-122.

Fleck, N., Korchia, M., \& Le Roy, I. (2012). Celebrities in advertising: Looking for congruence or likability?. Psychology \& Marketing, 29(9), 651-662.

Fleck, N., \& Maille, V. (2010). Thirty years of conflicting studies on the influence of congruence as perceived by the consumer: Overview, limitations and avenues for research. Recherche Et Applications En Marketing (English Edition), 25(4), 69-92.

Fleck, N., \& Quester, P. (2007). Birds of a feather flock together...definition, role and measure of congruence: An application to sponsorship. Psychology \& Marketing, 24(11), 975-1000. 
French, J. R. P. \& Raven, B. (1959). The bases of social power. In D. Cartwright \& A. Zander, Group dynamics (pp. 150-167). New York: Harper \& Row.

Friedman, H. \& Friedman, L. (1979) Endorser effectiveness by product type. Journal of Advertising Research, 19(5), 63-71.

Fiske, A. (2002) Using individualism and collectivism to compare cultures - A critique of the validity and measurement of the constructs: Comment on Oyserman et al. (2002). Psychological Bulletin, 128(1), 78-88.

Gahlaut, Kanika, “Salebrity”, India Today, December 20, 2004.

Gurel-Atay, E., \& Kahle, L. (2010). Celebrity endorsements and advertising effectiveness: The importance of value congruence. Advances In Consumer Research, 37, pp. 807-809.

Heider, F. (1958). The psychology of interpersonal relation. New York: Wiley

Hofstede, G., (1980) Culture's consequences: international differences in work-related values. Baverly Hills, CA: Sage Publications.

Hofstede, G. (1983) National cultures in four dimensions. International Studies of Management \& Organization, 13(1/2), 46-74.

Hofstede, G. (1991) Culture and organizations: Software of the mind. London: McGraw-Hill.

Hofstede, G., (2001) Culture's consequences: comparing values, behaviors, institutions and organizations across nations. Thousand Oaks, CA: Sage Publications.

Holden, N. (2004) Why marketers need a new concept of culture for the global knowledge economy. International Marketing Review, 21(6), 563-572.

Kamins, M., Brand, M., Hoeke, S. \& Moe, J. (1989) Two-sided versus one-sided celebrity endorsements: The impact on advertising effectiveness and credibility. Journal of Advertising, 18(2), 4-10.

Kamins, M. \& Gupta, K. (1994) Congruence between spokesperson and product type: A matchup hypothesis perspective. Psychology \& Marketing, 11(6), 569-586.

Kluckhohn, F.R. \& Strodtbeck, F.Z. (1961) Variations in Value Orientations. WestPort, CT: Greenwood Press.

Kroeber, A. L. \& Parsons, T. (1958) The concepts of culture and of social system. American Sociological Review, 23 (5), 582-583.

Lee, J., \& Thorson, E. (2008). The impact of celebrity-product incongruence on the effectiveness of product endorsement. Journal Of Advertising Research, 48(3), 433-449. 
Mahanta, Vinod \& Sangameshwaran, Prasad. The great Indian celebrity trap in advertising, The Economic Times, February 3, 2010.

Markus, H. \& Kitayama, S. (1991) Culture and the self: Implications for cognition, emotion, and motivation. Psychological Review, 98(2), 224-253.

Mathur, L., Mathur, I., \& Rangan, N. (1997). The wealth effects associated with a celebrity endorser: The Michael Jordan phenomenon. Journal of Advertising Research, 37(3), 6773.

McCracken, G. (1989) Who is the celebrity endorser? Cultural foundations of the endorsement process. Journal of Consumer Research, 16(3), 310-321.

McGuire. W. J. (1985) Attitudes and attitude change." in Gardner Lindzey and Elliot Aronson (eds.) Handbook of Social Psychology. Vol. 2, New York: Random House.

Misra, S. \& Beatty, S. (1990) Celebrity spokesperson and brand congruence: An assessment of recall and affect. Journal of Business Research, 21(2), 159-171.

Money, R., Shimp, T. \& Sakano, T. (2006) Celebrity endorsements in Japan and the United States: Is negative information all that harmful?. Journal of Advertising Research, 46(1), 113-123.

Ohanian, R. (1991). The impact of celebrity spokespersons' perceived image on consumers' intention to purchase. Journal of Advertising Research, 31(1), 46-54.

Osgood, C. E., \& Tannenbaum, P. H. (1955). The principle of congruity. Psychological Review, 62(January), 42-55.

Over the years: Shahrukh Khan, from fauji to king, The Hindustan Times, September 17, 2012

Oyserman, D., Coon, H. \& Kemmelmeier, M. (2002). Rethinking individualism and collectivism: Evaluation of theoretical assumptions and meta-analyses. Psychological Bulletin, 128(1), 3-72.

Parsons, T. (1951) The social system. Glencoe, Illinois: Free Press.

Petersen, A., Kushwaha, T., \& Kumar, V. (2013), The relationship between marketing efforts and customer behavior: Does national culture matter?", Working Paper, University of North Carolina, Kenan-Flagler Business School.

Rice, D., Kelting, K., \& Lutz, R. J. (2012). Multiple endorsers and multiple endorsements: The influence of message repetition, source congruence and involvement on brand attitudes. Journal Of Consumer Psychology, 22(2), 249-259.

Sangameshwaran, Prasad. Who's safer bet as brand ambassador, The Economic Times, March 25, 2009. 
Schwartz, S. H. (1999) A theory of cultural values and some implications for work. Applied Psychology: An International Review, 48(1), 23-47.

Schwartz, S. H. (1994) Are there universal aspects in the structure and contents of human values? Journal of Social Issues, 50(4), 19-45.

Singh, Harsimran. Katrina is queen on web too...but KING KHAN languishes at the bottom, The Economic Times, July 26, 2009.

Singh, N. (2004) From cultural models to cultural categories: A framework for cultural analysis. Journal of American Academy of Business, 5(1/2), 95-101.

Sojka, J. Z. \& Tansuhaj, P. S. (1995) Cross-cultural consumer research: A twenty-year review. Advances in Consumer Research, 22(1), 461-474.

Taylor, E. (1964) Culture defined, in L. A. Coser and B. Rosenberg (eds) Sociological theory: A book of readings. West Drayton: Collier-Macmillan.

Till, Brian D. (1998) Using celebrity endorsers effectively: Lessons from associative learning, The Journal of Product and Brand Management, 7(5), 400-410.

Till, B. \& Shimp, T. (1998) Endorsers in advertising: The case of negative celebrity information. Journal of Advertising, 27(1), 67-82.

Triandis, H. (2004) The many dimensions of culture. Academy of Management Executive, $18(1), 88-93$.

Tripp, C., Jensen, T., \& Carlson, L. (1994). The effects of multiple product endorsements by celebrities on consumers' attitudes and intentions. Journal of Consumer Research, 20(4), 535-547.

Trompenaars, A. (1993) Riding the waves of culture: Understanding diversity in global business. London: Nicholas Brealey Publishing. 